Resumen por la autora, Christianna Smith, Universidad Cornell, Ithaca.

Estudio del lipoide contenido en el túbulo del riñón.

El presente estudio sobre el lipoide del riñón conduce a las siguientes conclusiones: 1. La presencia de lipoides enmascarados o libres es característica de las células normales del riñón, y pueden ponerse de manifiesto después de la fijación mediante el bicromato en caliente. 2. En ciertas especies (por ejemplo, el gato) diferentes porciones del túbulo presentan formaciones lipoides caracteristicas que pueden indicar una diferencia funcional. 3. Los bastones mitocondriales de la rama ascendente del asa medular son intensamente lipoideos por naturaleza, resolviéndose en granos de lipoide bajo ciertas condiciones. 4 . Las gotitas lipoideas que contienen un tanto por ciento elevado de oleína no se conservan con el método de Bell. 5. La presencia, distribución y, en algunos casos, la distribución característica de los lipoides en las células del riñón indican que peuden estar intímamente relacionados con procesos mećabólicos, además de la posible función que se les atribuye por algunos autores como agentes que influyen en el estado físico del protoplasma. La introducción del presente trabajo contiene una corta revisión del trabajo ya efectuado sobre el orígen y presencia de lipoides en los tejidos, y especialmente en las células del riñón. Las propiedades histoquímicas de los lipoides se describen y también el material y métodos empleados en el presente trabajo. La mayor parte de las observaciones fueron hechas sobre las células renales del gato, pero las del perro, conejo y rata fueron también examinadas. El trabajo termina con una discusion general de la significación de la presencia de lipoides en los tejidos.

Trunslation by José F. Nonidez

Carnegie Institution of Washington 


\section{A STUDY OF THE LIPOID CONTENT OF THE KIDNEY TUBULE}

\section{CHRISTIANYA SMITII}

Department of Histology and Embryology, Cornell University, Ithaca, New York FOURTEEN FIGURES (TWO PLATES)

\section{CONTENTS}

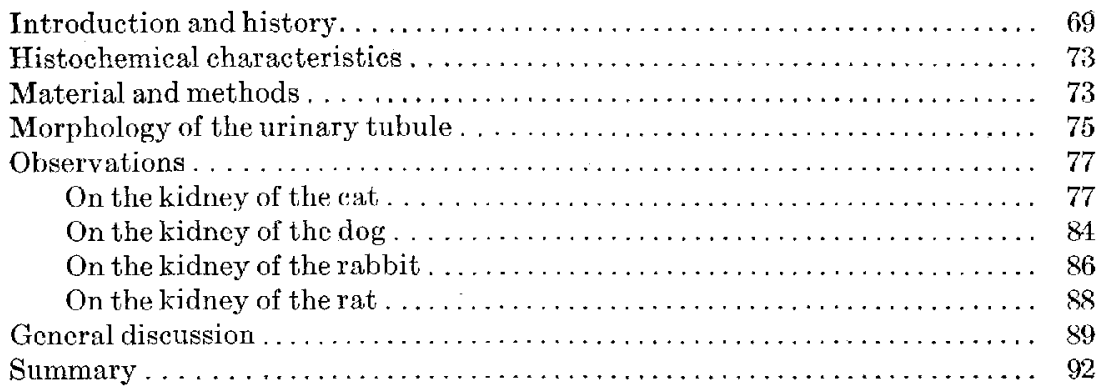

\section{INTRODUCTION}

The omnipresence of lipoids in the tissues has been pointed out by chemists and studied by many. Cowdry, in his excellent summary of the functional significance of mitochondria, which are related to the phospholipins, quotes Matthews ('15) apropos of this, who says that phospholipins are found in all cells, and that it is undoubtedly their function to produce, with cholesterol, the peculiar semifluid, semisolid state of protoplasm. However the presence of lipoids has been overlooked by histologists in general until quite recently, because they are dissolved in many fixers and require special technique to preserve them. That lipoids are present in kidney cells has been known, but almost always it has becn connected with pathological changes. Believing that microscopically lipoids could be demonstrated in normal cells, this study of the lipoid content of renal epithelium 
was undertaken at the suggestion of Dr. B. F. Kingsbury, whose kindly interest and generous help is gratefully acknowledged. The conclusions reached were that lipoids could be demonstrated in kidney cells by special technique, that the distribution and formations of the lipoids were more characteristic in some species than in others, and that some lipoids may be intracellular in origin.

Although it is agreed that lipoid is a poor term, chemically speaking (Leathes, '10), 'it is useful in histology to include fats, fatty acids, phosphatids, cholcsterol, etc., substances which have the same solvents and which are found associated in cytoplasm," (Kingsbury '15), and as such it will be employed in this paper.

If these lipoids are universally present in cells, as it is believed they are by chemists and histologists (Fischer and Hooker, '17; Kingsbury, '15), the question arises as to the forms in which they exist and their relation to the other cell contents in the cell. Fischer and Hooker believe that in normal cells and fluids, liquids (Fischer and Hooker use the term 'fat') are present in finely divided form, kept so by various hydrated proteins, and that the amount of lipoid varies greatly not only in a given cell or body fluid under different physiological and pathological circumstances, but also at all times, in different cells and fluids. It is because of these fine emulsions, they say, that large amounts of lipoids may be present in certain tissues and not betray themselves optically or by ordinary fat stains. According to this interpretation, fatty degeneration is merely a coarsening of the normally fine emulsions due to the separation of the lipoids because of an interference with the hydration of the proteins. This interference is, according to them, acid production, caused by substances such as phosphorus, phlorizin, alcohol, and conditions of anaemia or general circulatory disturbances.

That some of the lipoids in cells are present in intimate mixtures has already been pointed out (Kingsbury, '11), and that one of these mixtures is represented by mitochondria seems at present unquestioned. Cowdry ('16) in the paper to which reference has already been made, gives the following summary of the chemistry 
of mitochondria. Mitochondria are soluble, wholly or partially in fat solvents, alcohol, ether, chloroform, and dilute acetic acid, and the part which is not soluble is a protein (albumin?). They are rendered insoluble by chromation. Mitochondria do not stain with sudan III or scarlet red and are blackened only at times with osmic acid. Because of their lipoid nature, some have sought to find in them the source of lipoids in the cell, while others believe they themselves arise from lipoids (Cowdry, '16).

The problem of the source of visible lipoids in tissues is one that has aroused much interest and has been very much involved in the questions of fatty infiltration and fatty degeneration. One explanation that visible 'fat' is due to the coarsening of a fine emulsion of lipoid has already been given. Others believe that fatty infiltration is an excessive deposition of fat and that fatty degeneration is a conversion of cell substance into fat. (Virchow from Fischer and Hooker). E. T. Bell ('14-'15) refers to two divergent opinions on this subject in his paper on "The Differential Staining of Fats." Rosenfeld ('04) and Kraus ('03) believe that kidney fat is derived mainly from the destruction of intracellular lipoids or from structural changes in the cytoplasm whereby finely divided fat becomes visible. Ribbort ('03) says that lipoids are mainly extracellular in origin and that the origin of intracellular lipoids is comparatively unimportant. Bell suggests that oleic fat is extracellular in origin and other lipoids are intracellular. From this brief account of the problem of lipoids in tissues, it can be readily scen that the question is one of importance, and the significance of the presence of lipoids will be taken up in the general discussion at the end of the paper.

Just as it has been brought out in the first part of the introduction that tissues possess lipoids, which are difficult in general to demonstrate microscopically, so is it true concerning the lipoid content of the kidney. Krauss, in 1904, makes the statement, "that tissues that are microscopically fat free, and look normal in general, for example, kidney cells, may contain 20 per cent of fat." As late as 1909-1910, Mayer and Rathery state that no fat disclosed by usual reactions is found in the kidney cells of mammals. 
In his study of the lipoid content of epithelium, cartilage, and muscle fibers of the ox, E. T. Bell ('09) makes some observations on the lipoids present in the kidney, and finds that the renal cells of some ox foetuses contained lipoid droplets, and that the cortical renal cells of two large steers were loaded with lipoids. ${ }^{1}$ Other observations, not his own, are recorded by Bell in this paper. Aschoff ('97) and Pfeiffer ('99) described lipoids in the kidney and other organs of new-born children; Hansemann ('97) found fat, 1) in the human kidney, an occurrence which he considered usually pathological, but which might be normal; 2) in swine, especially when fattened, which he thought abnormal and analogous to obesity in man; 3) in cats and dogs. In 1910, Bell examined the tissues of calves, cats, dogs, rats, and frogs, and found usually a large number of lipoid droplets in the convoluted tubules, a fewer number in the collecting tubules, and in some tubules none. He observed also that the amount of lipoid in the kidney varies greatly, the cat showing the greatest amount, and the ox least. In his work, "On the Differential Staining of Fats" ('14-'15), Bell used the kidney tissue of human and rat as one kind of material.

Policard mentions in most cases in his work on the histogenesis and histology of the renal epithelium only the presence of lipoids. In his paper on the "Functioning of the Kidney of Frog" ('10), he makes, however, the following summary of his observations in regard to the lipoids in the convoluted tubules. The formations of lipoids which reduce osmic acid, but which stain with copper hematoxylin, after the method of Weigert-Regaud, are of three kinds: First, there are flakes of material which stain gray that are cnclosed in vacuoles. These are, by him, considered artifacts. Secondly, very fine granules are present which stain blue-black and which correspond to the innermost subcuticular vacuoles described by various observers, but whether it is the wall of the vacuole or the substance contained which stains he does not know. Thirdly, in the region of the nucleus,

\footnotetext{
I The tcrm 'lipoid' has been substituted here wherever Bell has used the word 'fat,' although he uses 'fat' in the general sense to include true fats and other lipoids.
} 
larger grains exist at the periphery of the section which he considers badly fixed mitochondria. These flakes and granules which Policard describes are quite clearly lipoids in combination that are stained by the mitochondrial technique which he used. Evidently Policard does not take into consideration the fact that in the preservation of lipoids the best fixation of a mass of tissue is at its periphery, while at the center of the mass the fixation may be incomplete. In discussing other portions of the tubule, Policard mentions that lipoids are rarely found in that portion which corresponds to the ascending limb of the medullary loop (loop of Henle).

MacNider ('16, '18), in his work on nephropathic dogs, refers to the presence of fat in the ascending limb of the medullary loop as of frequent occurrence.

In his investigation of the fat infiltration of the cat's kidney, Mottram ('16) observes that lipoids are present in the convoluted tubules and rarcly in the straight tubules. He checks up in this paper, an observation made by Leathes, that the lipoid content of the cat's kidney, instead of being more unsaturated than that of of the liver and 'lipoid tissue,' as it is in the kidneys of other animals, man, dog, goat, pig, is sometimes more saturated than 'lipoid tissuc' and never as unsaturated as that of the liver.

\section{IIISTOCHEMICAL CHARACTERISTICS}

The observations made by Bell in his several papers in regard to the histochemical properties of lipoids may be tabulated as shown on page 74. Most of these observations were made in the study of muscle, but they are applicable as well to lipoids in the kidney. Fats that are solid at ordinary room temperature do not form any part of the stainable substance, although such fats may be present in small quantity.

\section{MATERIAL AND METIIODS}

The material used in this investigation was taken from cats, dogs, rabbits, and white rats that were killed by illuminating gas, and the tissue fixed immediately or at different intervals 


\begin{tabular}{|c|c|c|c|}
\hline & I & II & III \\
\hline \multicolumn{4}{|c|}{ Soluble in absolute alcohol or ether } \\
\hline Refraction & Strongly refractive & $\begin{array}{l}\text { Intermediately re- } \\
\text { fractive }\end{array}$ & Faintly refractive \\
\hline $\begin{array}{l}\text { Effect of fixatives } \\
\text { and postmortem } \\
\text { changes }\end{array}$ & $\begin{array}{l}\text { Little affected by } \\
\text { fixatives (except } \\
\text { formalin) or post- } \\
\text { mortem changes }\end{array}$ & $\begin{array}{l}\text { Gradually disap- } \\
\text { pear under the } \\
\text { influence of fixing } \\
\text { agents, and post- } \\
\text { mortem changes. } \\
\text { Prescrved r by } \\
\text { Bell's } 10 \text { per } \\
\text { cent dichromate } \\
\text { method }\end{array}$ & $\begin{array}{l}\text { Disappcar in most } \\
\text { fixing agents, } \\
\text { such as formalin } \\
\text { and postmortem } \\
\text { changes. Pre- } \\
\text { scrved by Bell's } \\
10 \text { per cent di- } \\
\text { chromatemethod }\end{array}$ \\
\hline
\end{tabular}

Staining and fixing reactions

\begin{tabular}{l|l|l|l}
\hline $\begin{array}{l}\text { 1. Scarlet red, fresh } \\
\text { material }\end{array}$ & Intensely stained & $\begin{array}{l}\text { Less intensely } \\
\text { stained }\end{array}$ & Faintly stained \\
$\begin{array}{l}\text { 2. Sudan III after } \\
\text { Bell }\end{array}$ & $\begin{array}{l}\text { Annular form of } \\
\text { droplet }\end{array}$ & Solid red droplet \\
3. Osmic acid & Stain black & $\begin{array}{c}\text { Stain brown or not } \\
\text { colored }\end{array}$ & Not stained \\
\hline $\begin{array}{l}\text { Chemical composi- } \\
\text { tion }\end{array}$ & Essentially olein & $\begin{array}{c}\text { Olein mixed with } \\
\text { some other fatty } \\
\text { substance, e.g., } \\
\text { cholesterol }\end{array}$ & $\begin{array}{l}\text { Low melting fat } \\
\text { (butyrin) }\end{array}$ \\
\hline
\end{tabular}

after death. Bell ('11) and Bullard ('12) emphasized the necessity of using fresh material if all fat prosent was to be demonstrated, and Policard and Garnier (05) found that renal cells underwent postmortem changes fiftcen minutes after dcath.

In the study of the lipoids, three kinds of material are usually employed: fresh tissue; that which has been fixed in a dichromate solution where the reduction of the dichromate renders the fat insoluble and stainable with hematoxylin, and that which has been preserved in osmic acid, which certain lipoids will reduce with subsequent blackening of them. In order to get as complete an idea as possible of the lipoid content of cells, these three methods should be used, one as a check for the other. The 
solutions employed which depended on the presence of the dichromate with further mordantage in a simple solution of it, for the preservation of lipoids, were Helly, Zenker, modifications of them, and Regaud's fluid. Bell's ('14, '15) acidified 10 per cent potassium dichromate was uscd and kept at a temperature of $51^{\circ}$ for forty-eight hours. The fixers which contained osmic acid were Flemming's and Benda's fluids, and a solution of 10 per cent potassium dichromate and 2 per cent osmic acid.

In preparing material for fixation, it was found best to use both radial and tangential sections, cut from 1 to $2 \mathrm{~mm}$. in thickness, in order that the preservation of the lipoids would be as complete as possible. Lipoids which reduced osmic acid were found to be kept best if the imbedding were done in parlodion according to Kingsbury ('11). More stainable lipoids with better preservation were found after fixation, in a solution of potassium dichromate and osmic acid. The results obtained were practically the same whether heat was employed or not, so that it seems clear that the results were due to the combination of the dichromate and osmic acid.

Free-hand sections of fresh material were stained in an alkaline alcoholic solution of scarlet red (Bullard, '12, '13), which both Bell and Bullard consider the most efficient stain for the demonstration of fat granules in fresh or frozen scetions. One per cent osmic acid was also used. In the fixed material, absolute alcohol was avoided throughout the work. Sudan III and hematoxylin were used as stains after Bell's dichromate fixation, iron hematoxylin and copper hematoxylin after dichromate fixations such as Zenker and Helly, and anilin acid fuchsin and hematoxylin after osmic acid solutions.

\section{MORPIIOLOGY OF THE URINARY TUBULE}

In the study of the lipoid content of the kidney, it was found that a knowledge of the parts of the renal tubule with their characteristic kinds of epithelium was necessary in order to rightly interpret the distribution of the lipoids and their relation to the tubule, and, further, to avoid any ambiguity. The terms 
recommended by Huber ('09) have been used in this paper. The parts of the tubule and the kinds of epithelium are, briefly, as follows: First, comes the renal corpuscle with its doublewalled capsule of flat epithelium. Continuous with the epithelium of the outer wall of the capsule is the short, often indistinct, neck which unites the capsule with the first portion of the tubule, the proximal convoluted tubule with the medullary segment. The epithelial linings of the proximal convoluted portion and the medullary segment are essentially the same throughout. The high cells, with striated free border, indistinct cell boundaries, and rodded protoplasm of the basal portions of the cell are all distinguishing features. The medullary segment of the proximal convoluted portion is followed by that part of the tubule known as the loop of Henle, but for which Huber suggests the name, medullary loop. The parts of this are the proximal or descending limb, the distal or ascending limb, and the crest. The epithelium of the descending limb is of a thin pavement type, with relatively large nuclei, which reach from the top to the bottom of the cell and may cause the cell to bulge into the lumen. The crest of the loop may be formed either by the thin descending limb, if the loop is long, or if it is short, by the thick ascending one. The ascending limb extends to the renal corpuscle of its own tubule, and is followed at that point by the distal convoluted portion, which extends to the collecting tubule. Policard ('12-'13) states that the type of epithelium characteristic of the ascending limb is continuous in the distal convoluted tubule, and Huber does not believe the variations which may be present in the different parts great enough to warrant the recognition of other types. Huber, however, considers the epithelium as low, columnar, with indistinct cell boundaries, granular protoplasm, indistinct basal striations, and as possessing no striated free border. In his work on Batrachian and mammalian specimens ('04, '10, '12), Policard points out that this segment possesses very thick rods or bâtonnets, which extend from the base of the cell to the edge bordering the lumen, a characteristic which has been found true in the forms studied during this work. A discussion of this type of epithelium will 
be reserved until the treatment of the ascending limb of the cat's kidney, when its lipoid content is taken up. The transition between the distal convoluted and collecting tubules is gradual, and the clear type of epithelium characteristic of this portion needs no additional comment.

\section{OBSERVATIONS}

In this study of the lipoid content of the kidneys, cats were used more extensively, because the lipoids present were very easily demonstrated by fixers containing osmic acid. Definitely cut pieces of the kidneys from thirty-four cats were fixed in either Benda's or Flemming's fluids. All of these were found to contain lipoids that would reduce osmium tetroxid. Eleven of these cats were from 41 to $52 \mathrm{~cm}$. in length measuring from occipital crest to base of tail, fourteen were 30 to $38 \mathrm{~cm}$., nine 18 to $23 \mathrm{~cm}$. - that is, grown cats, half-grown cats, and small kittens. Of these, one died, four were killed by ether, and the rest by illuminating gas. The older full-grown cats had kidneys which were light in color and possibly pathological. Of the half-grown cats and kittens, only one pair of kidneys were found to be pathological upon gross examination, the rest appearing normal. Except for two kittens which had sore eyes, the external and internal appearances differed only in general thinness or fatness. Taking into consideration the above observations, one could almost always foretell how the section of kidney would look after it had been placed in Benda's or Flemming's fluid. A kidney of a very thin kitten or half-grown cat would have a cortex with very characteristic black rays; a fat kitten would possess a kidney, the cortex of which would blacken as a whole, while an old cat, fat or thin, would have a kidney with an intensely black cortex (figs. 1 to 8). In this gross examination of the kidney, the transition between the blackened cortex and lighter medulla was very evident as a distinct and clear-cut line. That the cat possesses fat different in amount, distribution, and composition from other animals was evident in this vory superficial examination, and may have some correlation with the obser- 
vations of Mottram ('16) in regard to the saturation of the fats present in the cat's kidney.

As a typical example of a kidnoy whose cortex is characterized by blackened rays, one will be studied from a $22-\mathrm{cm}$. kitten which was quite thin. The kitten was killed by gas and its tissue fixed immediately. The kidney appeared normal and healthy. As the appearance of lipoids depends upon its preservation and staining, the lipoid content will be examined in its relation to the methods used.

T'en per cent formalin and scarlet red. Free-hand sections were made from material that had been in 10 per cent formalin for about a week, and stained with an alkaline alcoholic solution of scarlet red (Bullard, '12-'13). Formalin material was used in this case bccause the lipoids of the kidney of cat are little affected by it. The rayed appearance of the cortex noted in the gross examination of tissue fixed in Benda's was apparent here, and the rays proved to be composed of tubules containing heavily stained lipoid granules in the medullary rays. The tubules of the labyrinth and medulla also contained granules, but they were much finer than those in the rays.

Potassium bichromate and sudan III. This method was first used by Rell, who said it would stain all granules seen in a fresh specimen and would also differentiate those containing olein from other lipoids. The medullary rays which were stained with Benda's or scarlet red, thereby standing out prominently because of their intense staining, were here very light in color, and the tubules of the labyrinth were darker. This variation was due to the fact that those granules which were deeply stained by scarlet red or Benda's were stained only at the periphery or not at all with sudan III after chromation. These droplets, then, could be said to contain olein because they reduce osmic acid and because they were chromated on the surface or not at all by Bell's method, or are what he called annular droplets. The medulla was also divided into two regions, one, corresponding to the outer zone of Peter, which lies next to the cortex, contained more deeply staining tubules than the inner zone or papilla. 
When the cortex was examined more closely, it was found that the cells of the proximal convoluted tubule which had stained deeply, contained a large number of lipoid granules, some portions of the tubules more than others. As stated by Bell, when there was a small amount of lipoid present, the granules were collected at the base of the cell, and when a large amount was present, the granules were scattered through the cell. Where the lipoid was stained, the mitochondrial filaments stood out among them in contrast very clearly. Although there was a tendency for one tubule to have the same kind of droplets, it was very common to find in the same tubule both annular and solid forms. In some sections of annular droplets, a diffusion of the lipoid into the surrounding cytoplasm could be seen quite plainly. It was also noted that many irregular-shaped granules seemed to be composed of two or more droplets.

The tubules containing the very large droplets which stained intensely with osmic acid and scarlet red, and not at all or very little with sudan III, were the medullary segments of the proximal convoluted tubule. Although Bell describes the type of droplets which contains olein as annular, from observations on both normal and pathological kidneys where droplets which stained intensely black were very abundant, it would be seen that the larger droplets were not preserved at all and represented vacuoles. That this condition was not due to sections where the fixation was incomplete was shown by the fact that neighboring proximal convoluted tubules possessed lipoid which stained with sudan III (fig. 12).

The transition from the medullary segments of the proximal convoluted tubule to the descending limb was very sharp and the cause of the clear-cut line apparently between the cortex and the medulla which was noticed in the gross examination. The pavement epithelial cells of this part of the medullary loop or the loop of Henle possessed solid lipoid granules, quite numerous and large in proportion to the amount of cytoplasm in the cells. The ascending limb of the loop had an appearance very different from the other portions of the renal tubule because of the presence of the rods which Policard deseribes ('05, '10, '12, '13). Although 
these are called mitochondrial rods, and although Benda considers them mitochondria properly speaking, Policard does not agree for the following reasons: 1) Mitochondria are flexous filaments, and these rods are like sticks arranged in bundles, on cross-section appearing like cardiac muscle ('05); 2). these 'bâtonnets' are more easily preserved than mitochondria, although mitochondrial technique brings them out more clearly (10); 3) mitochondrial filaments in the proximal convoluted segment vary in form, becoming at times granular normally and during autolysis, while the rods of the third segment (which corresponds to the ascending limb of the medullary loop) never becomes granular normally nor during autolysis ('10). As to their nature; Policard describes them as, "protoplasmic rods, the surface of which seems to be covered with a lipoid substance" (10).

That these rods are lipoids or fatty in nature is shown very olearly in these sections, and it is because sudan III is soluble in them that the region of the medulla next to the cortex is stained more deeply red. In thin sections where the rods were not so closely packed that their individuality was hard to determine, two types could be distinguished. One form corresponded to the homogeneous rods of Policard, and they appeared like annular droplets drawn out to form rods which varied in length and width, some being slightly irregular. It may be possible that the method of fixation with the heat may have affected some of the rods and that they were atypical. The other form was composed of small granules arranged in rows (fig. 9). This form of the rods is quite contradictory to Policard's description of them. Small annular droplets and solid granules were present which might be interpreted as sections or tips of rods or distinct in themselves.

The distal convoluted tubule had epithelium of the same heavily rodded character as that of the ascending limb of the medullary loop, and the cells of the collecting tubules contained a few solid fat granules. One portion of the renal tubule has not been discussed and that is Bowman's capsule. The flat epithelium of the capsule also possesses lipoid granules, as do the other segments of the tubule. 
Ten per cent potassium dichromate and osmic acid. Ten per cent potassium dichromate and 2 per cent osmic acid were used in the proportions of four to one and $35 \mathrm{cc}$. were acidified by three drops of glacial acetic acid. The tissue was subjected to a temperature of $51^{\circ}$ for forty-eight hours. Material treated in this way showed the fat which reduces osmic acid more clearly and abundantly than tissue fixed in either Flemming's or Benda's fluid. In imbedding, both paraffin and parlodion were used, for, although more fat is preserved in parlodion sections, paraffin ones were found very useful in definitely locating the granules in the different regions of the tubule.

The rays which were described as staining black in pieces of tissues fixed in Benda's fluid stood out very clearly and intensely and the labyrinth was left unstained, except for some very fine granules (figs. 5 to 7 ). The same regions of the medulla were present as were described for material fixed in 10 per cent dichromate and stained with sudan III. Here the outer zone appeared gray-black and the inner zone was left unstained. The large black globules were present in the medullary segment of the proximal convoluted tubule and were the same as those which stained intensely red and not at all or only at the periphery with sudan III. Other parts of the proximal convoluted tubule had very small granules at the base of the cells which did not stain an intense black. In the convoluted tubules of the kidney of a $23-\mathrm{cm}$. kitten, there was the same linear arrangement of fine fat granules, though not so regularly placed, as may be found in the ascending limb of the medullary loop. These formations in the ascending limb will be described in the next paragraph. This linear arrangement of the lipoids in other portions of the urinary tubule besides the ascending limb may be due to the position of the lipoids in relation to mitochondria either passively or in consideration of a more intimate connection, or it may be an early stage of fat formation independent of mitochandria (fig. 14).

No lipoid was visible in the descending limb of the medullary loop which stained black with osmic acid. In the ascending limbs, those rods which, at times appeared granular and at other 
times homogeneous when fixed and stained by Bell's method, were here very definitely composed of granules which stained black (fig. 13). These granular filaments starting at the base of the cell extended to the edge bordering the lumen, and occupied the space between the nucleus and periphery of the cell. 'They ran parallel to each other and their beaded appearance was absolutely clear. In most tubules, these granular filaments so very distinct in the medulla were not preserved in the cortex. This was probably due to imperfect preservation, for in the dog's kidney, which will be described later, they were well preserved in the cortex. The conclusion seems justified, therefore, that these homogeneous rods which Policard describes as "protoplasmic rods with a lipoid surface covering" never becoming granular, are lipoids and do become granular filaments which stain black with osmic acid when treated with certain fixers, as a mixture of potassium dichromate and osmic acid, with or without the application of heat.

The collecting tubules did not contain lipoids that reduced osmic acid.

Benda's fluid. Material fixed in Benda's fluid showed the same characteristics as that fixed in potassium dichromate and osmic acid. The preservation of the lipoids, as it has been stated before, was better in 7 the bichromate solutions.

One per cent osmic acid. In a simple solution of osmic acid, the same details were evident that were present in the other osmic-acid fixers. The rods of the ascending limb of the medullary loop appear granular upon focusing, but homogeneous when in packets.

The discussion of the tissues fixed in Helly's fluid, Zenker, and Regaud will be omitted in this paper and taken up in another, when the effects of different fixers and the lipoids of the kidney will be studied in their relation to mitochondria.

As an example of a very fat kidney with a very black cortex, one will be taken from a cat which measured $46 \mathrm{~cm}$. occipital crest to the base of the tail. This kidney possessed a very yellow cortex in the fresh condition and was probably pathological, as the liver appeared to be also. 
Ten per cent formalin and scarlet red. Very large globules which were present in the cells stained with scarlet red in all of the tubules of the cortex.

Ten per cent dichromate and sudan III. Just as in the kitten, those granules which stained deeply with scarlet red and black with osmic acid were not preserved by this method, and the cortex appeared as if composed of vacuoles. The lipoids in the descending limbs of the medullary loop, in the ascending limb, and the collecting tubules did stain, however, and this showed that the non-preservation of the fat in proximal tubules was not due to poor preservation (fig. 10). The cells of the medullary segment of the proximal convoluted tubules were desquamating and stained diffusely with red, no lipoid droplets being present. The appearance of the very fat kidney differed, then, from a kidney with the rayed appearance of the cortex in that all the tubules were very full of large lipoid granules and the lower portion of the medullary rays did not contain lipoid droplets.

Benda's fuid. In fluids containing osmic acid, the cortex was blackened intensely (fig. 8). All the tubules were affected except portions of the medullary rays. These tubules, the medullary segments of the proximal convoluted tubule, whose cells were desquamating, did not blacken, and the limbs of the medullary loop and collecting tubules contained very fine granules. A linear arrangement of these could often be seen. In a section fixed in Benda's fluid and stained in anilin acid fuchsin, the granular appearance of the mitochondria, and rods of the ascending limb of the medullary loop stood out very clearly.

The cortex of the kidney of a very fat $18 \frac{1}{2}-\mathrm{cm}$. kitten looked more like the cortex of the kidney of a fat eat. The proximal convoluted tubules in the labyrinth contained fine and moderately coarse granules, while the medullary rays and medulla were unstained (figs. 3 and 4).

A free-hand section of the kidney of a foetal cat which had been preserved in formalin several months was stained with a fresh solution of sudan III and found to be abundantly supplied with lipoid granules. 
From these observations of the lipoid content of the kidney of the cat, it can be seen that there is a characteristic distribution of the lipoid granules which varies under different conditions, the normal and pathological not appearing the same. 'Because of the abundant supply of lipoids, their characteristic formations, such as the granular forms of the rods of the ascending limbs, and distribution in the cat's kidney, it should be a favorable place in which to study the relation of lipoids to mitochondria.

The lipoid content of the cat's kidney may be summarized as on page 85 .

The results obtained from the study of the kidneys of other animals are added here with the realization of their incompleteness and the need of further study. E. T. Bell summarizes the factors which have caused confusion in the study of fat in muscle fibers ('12). They might well be repeated here in regard to the lipoid content of the kidney. They are the following: 1) the character of the fat stain employed; 2) the species of animal; 3 ) the character of the animal's food; 4) the general nutritive condition of the animal; 5) the effect of fixatives; 6 ) the effect of postmortem changes. That the character of the fat stain and fixatives employed and conditions of the animal are very important is easily seen from the study of the lipoid content of the cat's kidney. That the species of the animal and effect of postmortem changes must also be considered is evident from the following observations on the dog, rat, and rabbit.

\section{Dog}

Although it might be expected that the dog and cat would have kidneys very similar in their lipoid content, the reverse was found to be true. Of the six dogs examined, none presented the rayed appearance of the cortex so characteristic of the kittens and half-grown cats, but looked more nearly like the very fat kitten (fig. 3). Two of these six dogs were five-day-old puppies, one a puppy not yet weaned, but whose exact age was not known, two were two weeks and five days old, and one a half-grown $\operatorname{dog}$ with the mange. On the kidney of the puppy of unknown age the following observations were made. 


\begin{tabular}{|c|c|c|c|}
\hline 飬䍚 & 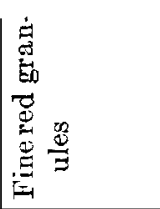 & 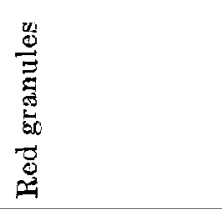 & 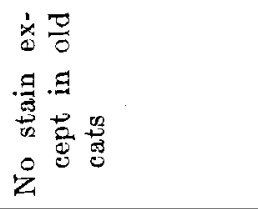 \\
\hline 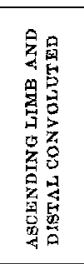 & 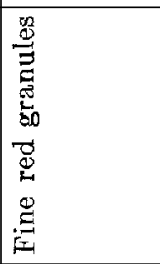 & 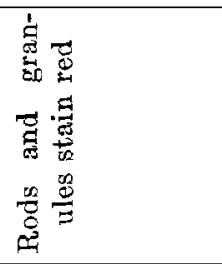 & 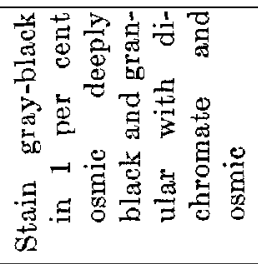 \\
\hline 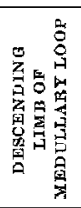 & 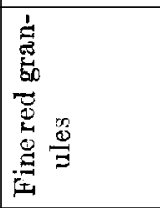 & 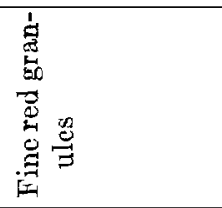 & 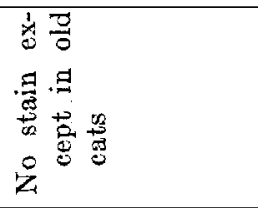 \\
\hline 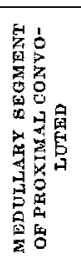 & 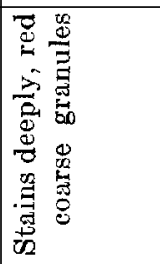 & 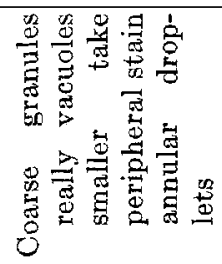 & 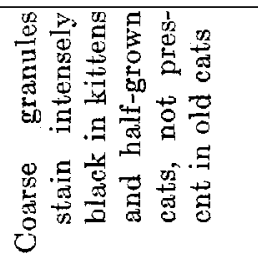 \\
\hline 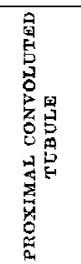 & 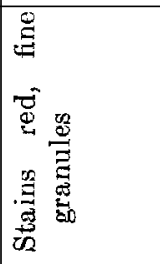 & 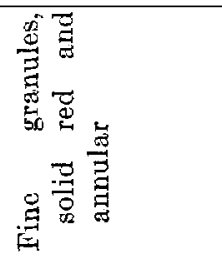 & 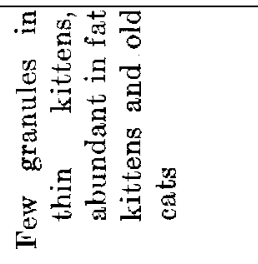 \\
\hline 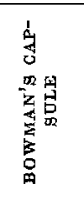 & 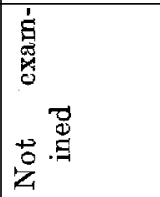 & 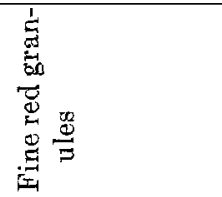 & 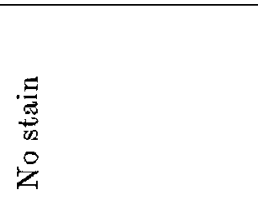 \\
\hline & 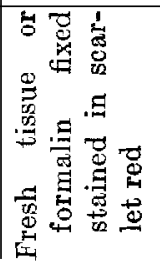 & 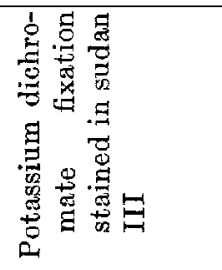 & 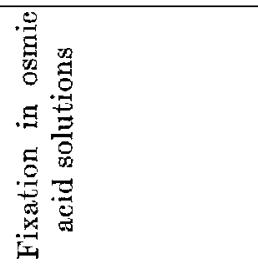 \\
\hline
\end{tabular}


Ten per cent formalin and scarlet red. No granules were preserved in the proximal convoluted tubules in most regions. Some red-staining droplets were found in the tubules bordering the medullary ray and in the medullary loop and collecting tubule.

Ten per cent potassium dichromate and sudan III. The cytoplasm of the cells of the proximal convoluted tubule stained diffusely with red and contained irregular masses which might be called sudanophile precipitate by Bell ('14-'15) or perhaps, lipoids which have become dissolved in the cells during the fixation with application of heat. The lipoid granules in the ascending and descending limbs of the medullary loop and in the collecting tubules showed clearly.

Ten per cent potassium dichromate and osmic acid. The lipoids which blackened with osmic acid were present as fine granules in the ascending limbs of the medullary loop, and the lower portions of tubules which were interpreted as the medullary segments of the proximal convoluted tubules and were found in the labyrinth bordering the medullary ray. In the ascending limbs of the medullary loop in the cortex, the granular rods which were so clear in the medulla of the cat, were present, though not preserved in the medulla (fig. 11). In 1 per cent osmic acid, the rods in the ascending limb appeared homogeneous.

\section{Rabbit}

As the kidney of the dog differed from that of the cat in its lipoid content, so also is the kidney of the rabbit different from both of them. Kidneys of eleven rabbits were examined which had been fixed in Benda's fluid, and no lipoids which would reduce osmic acid were observed. Four of these rabbits were from seven days to seven and one-half weeks old, and observations made on the kidney of the seven and one-half wecks old rabbit will be given. The older rabbits whose ages were unknown were affected with coccidiosis, but the young rabbits were normal and healthy.

Fresh tissue. The cells of the tubules contained fine red granules when stained with scarlet red and some tubules con- 
tained cells with granules which stained brown with 1 per cent osmic acid.

Ten per cent potassium dichromate and sudan III. Unlike the kidney of the cat, the cortex did not possess any differentiation into rays, but, like it, possessed the two regions of the medulla, the outer zone staining more deeply. Granules were present in the cells of the proximal convoluted tubules which Bell called sudanophile precipitate, and for which he did not consider the evidence sufficient to consider as diffuse lipoids. According to Bell, sudanophile precipitate was not found in cells containing lipoid granules. As droplets were found in the tubules of the cortex which stained with scarlet red and browned with osmic acid, the conclusion was reached that the granules here wcre lipoids and not precipitates. The fatty nature of the rods in the ascending limbs of the medullary loops was evident although they stained very lightly.

Benda's fluid. Matcrial, autolyzed or not, showed no fat which would reduce osmic acid when Benda's fluid was used without the application of heat. Also, tissue which had not undergone autolysis, but was preserved in Benda's fluid kept at a temperature of $51^{\circ}$, exhibited no blackened granules. Sections which had autolyzed and were fixed in the way just mentioned presented a quite different appearance. Many black granules, short granular filaments, and rods were present in the cells of the cortical tubules and in the interstitial tissue of the cortex and medulla. Therefore, from these obscrvations it would seem that lipoids which reduce osmic acid are found in the kidney cells of the rabbit only after autolysis and fixation with heat. Ziegler, in his discussion of fatty degeneration (p. 199), says that "a process similar to that taking place within the body occurs during autolysis of tissue preserved aseptically in the incubator, fat droplets becoming visible in such tissues (Hensen, Wentcher, Kraus, Müller, and others)."

To summarize, fat is present in the kidney of the rabbit in the fresh condition which stains with sudan III after fixation with dichromate. After autolysis and fixation in an incubator, if osmic acid is present, there are some lipoids which will stain black. 
The rods of the ascending limb of Henle's loop again show their fatty nature, both in dichromate fixation and 1 per cent osmic acid.

\section{Rat}

The kidneys of rats were also examined and the results in general were like those obtained after the study of the renal cells of the rabbit. The kidneys of nineteen rats were cut and fixed. All of these rats were infected with lice, but the internal organs appeared normal except for one case of a cystic liver and one kidney that proved to be pathological when examined microscopically. Kidneys of rats which had been fed on fat diets were studied, and both these and controls were subjects to autolysis with fixation accompanied by heat. The results in brief were as follows: The rats possessed interstitial lipoid granules, which were especially abundant in the papilla. The presence of these granules made it difficult in the case of osmicacid fixations to distinguish always between intracellular and interstitial lipoid granules. In the fresh tissue and that preserved in formalin, the interstitial were the only lipoids that seemed to be present. Tissue fixed in 10 per cent dichromate with heat and stained with sudan III possessed granules which Bell would clearly call sudanophile precipitate, for they were not observed in the fresh condition. However, if lipoids which stain with osmic acid can be liberated after autolysis and fixation in an incubator, then it does not seem unreasonable to believe that some lipoids in combination in the cell might be sensitive to heat and liberated by it, chromated, and stainable with sudan III. Bell admits that more fat is demonstrable when higher temperatures are used, but does not yet interpret the sudanophile precipitate as diffuse fat. The granules were found in all the cells and the cytoplasm was unstained. The results with Benda's were the same as those observed in the rabbit.

Experiments to show the effect of fat diets were also carried out. This feeding was mostly on fat meat and bread soaked in fat, one rat was fed olive oil twice on the day it was killed. There was no infiltration of annular droplets as described by Bell, 
although with sudan III the granules appeared more numerous and somewhat more intensely stained, and a few faintly stained lipoid droplets were present in tissues fixed in an osmic-acid solution. These results did not check Bell's work. This may be because the feeding was not forced.

\section{GENERAL DISCUSSION}

As it was stated in the introduction, the conclusions reached in this study of the lipoid content of the kidneys were that lipoids could be demonstrated in kidney cells by special technique, that the distribution and formations of lipoids were more characteristic in some species than in others, and that some lipoids appeared to be intracellular in origin. The very definite distribution of the lipoids in the kidney of the cat has been shown, a distribution not so marked in the dog, and still less so in the rabbit and rat. However, in one segment there were lipoid formations peculiar to them all. These were the rods in the ascending limb of the medullary loop. As it was pointed out in reference to the cat and dog, these rods are lipoid in nature and are resolved into filaments composed of lipoid droplets under certain conditions. As these rods were considered by Benda mitochondria, properly speaking, and were called mitochondrial rods by Policard, although he denied their identity with them, the suggestion that there is a close relation between these rods and the formation of lipoid droplets in the cell ought not to be overlooked. In the granular forms which were seen after a fixation in $\mathbf{1 0}$ per cent dichromate and sudan III, a shadow of a rod could be seen between the granules. After a fixation in potassium dichromate and osmic acid, the droplets stood out clearly and separately in a definite linear arrangement. The presence of lipoid droplets in a linear arrangement in cells of other parts of the renal tubule is also very suggestive, although the evidence of their origin is not clear. Scott (16), in his work on the effect of phosphorus poisoning on mitochondria in pancreatic cells, says that after the mitochondria lose their filamentous form that they agglutinate and fuse to form droplets possessing the characteristic properties of lipoids. Mitochondria 
as a source of lipoids in the cells is discussed by Cowdry ('16), who thinks that it would require no great stretch of imagination to believe that this transformation could take place. The intracellular origin of lipoids does not, however, exclude an extracellular origin also, as shown by Bell in his experiments with rats (Bell, '14-'15).

Furthermore, the presence of lipoids in renal cells, either masked or free, the presence of large amounts of lipoids in cells of the proximal convoluted tubule where it is generally conceded either secretion or absorption takes place, the characteristic occurrence of typical lipoid formations (large droplets in the medullary limb of the proximal convoluted tubule in cat, and the rods in the ascending limb of the medullary loop), do not indicate that lipoids in kidney cells are merely passive structures, nor simply droplets formed by the coalescence of finer granules in an emulsion, but that they may be a direct expression of activity in the cell economy. Bullard ('12, '16) and Bell ('11) have concluded that lipoids in normal muscle cells are a reserve food supply. In discussing the rôle of fats (lipoids) in vital phenomena, Leathes ('10) says that they are most conspicuous as a reserve fund of fuel for growing and working cells, but that in virtue of their general chemical inertness are capable of being put to many uses in the organization of plants and animals, for instance, being essential to the cohesion and physical constitution of the protoplasm. In connection with the use of fat as fuel for working and growing cells, Hatai ('15) finds that a lipoid-free ration diminishes the normal rate of growth of the body in albino rats. Leathes also says that the unsaturated fats found in the cells of the body are broken down by successive oxidations until they are completely burnt to oxygen and water. Imrie, in his discussion of the fatty changes in the liver, heart, and kidney, says that the lipoids are oxidized in them to supply energy. In other words, the lipoids are reducing, and their probable relation to the reducing power of cytoplasm is discussed by Kingsbury (12) in his paper on cytoplasmic fixation. In this paper it is pointed out that as early as 1885 Ehrlich called attention to the 
need for oxygen and reducing power of the cells and tissues. In 1911, Unna showed that the cytopoasm is strongly reducing, while the nucleus is oxidative. Kingsbury then says that

if a close connection exists between reduetion processes and cytoplasmic (protoplasmic) activity, and if there is a parallel between protoplasmic activity and the demand for and consumption of oxygen in respiration, and the mitochondria are structural expressions thereof, the question will at once be raised as to the nature of the reducing substances, and it will be pointed out that the reducing substances that are present in cell respiration may far exceed in power the lipoid combinations that are believed to be present in the mitochondria. To this two comments may be offered: a) that, whereas, lipoid substances seem to be back of the mitochondrial reaction in some cases, it by no means follows that the reaction is due in every case to such substances, nor does it follow that structures demonstrated as mitochondria are in all instances closely connected with cytoplasmic respiration; $b$ ) that since in regions of the body where the reducing power is markedly developed, such as the medulla of the suprarenal gland, the myclinic nerve fiber, and the red blood corpuscle, there is an association with lipoids, it may well be that such substances are more intimately and universally connected with the reduction processes of the body than would at first appear.

From the pathological side, other evidence may be offered in favor of the theory that the lipoids in the cell are related to the oxidative process. In the first place, there is an increase in lipoid content in the kidney in diseases such as tuberculosis and pneumonia where there is a decrease in the amount of oxygen supplied, and also in anaemic infarcts (Ziegler-Imrie, '15). This would suggest that where the oxidation was decreased the lipoids were not removed, but stored. Bell ('12) produced this condition experimentally in muscle of frog's leg by ligaturing the leg and allowing only a small amount of blood to reach the muscle tissue. Others would explain this increase in fat as due to the acid production in the cell due to the lessened amount of oxygen (Fischer and Hooker, '17). The experimental physiological increase (Bell, '14-'15) might also be explained from the point of view that lipoids are reducing agents in cytoplasm, in that more lipoids were brought to the cells than were needed by the normal procezses, and were consequently stored. This would be in accord with the idea that they are a reserve fund of fuel. 
From this brief summary of the significance of lipoids in the cells, the evidence seems very strong that besides producing the peculiar semifluid, semisolid state of protoplasm, that the lipoids are in some way intimately connected with the metabolic processes.

\section{SLMMARY}

1. Lipoids are characteristically present in normal kidney cells either masked or free and are shown after a dichromate fixation with the application of heat.

2. In certain species (example, cat) different portions of the tubule have characteristic lipoid formations which may indicate a difference in function.

3. The mitochondrial rods of the ascending limb of the medullary loop are by nature strongly lipoid and are resolved into lipoid granules under certain conditions.

4. Lipoid droplets containing a large percentage of olein are not preserved by Bell's method.

5. The presence, distribution, and in some cases, characteristic distribution of lipoids in kidney cells suggest that they may be intimately connected with metabolic processes besides the possible function attributed to them by some of influencing the physical state of the protoplasm.

\section{BIBLIOGRAPHY}

BELL, E. T. 1909 On the occurrence of fat in the epithelium cartilage, and muscle fibers of the ox. Am. Jour. Anat., vol. 9, pp. 401-412.

1910 The staining of fats in epithelium and muscle fibers. Anat. Rec., vol. 4, pp. 199-212.

1911 Interstitial granules of striated musele. Internationale Monatschrift für Anatomie u. Physiologie, Bd. 28, S. 297-347.

1912 The interstitial granules (liposomes) in fatty metamorphoses of striated muscle. Journal of Path. and Bact., vol. 17, pp. 147-159.

1914. On the differential staining of fats. Journal of Pathology and Bacteriology, vol. 19, pp. 105-113.

Bullard, H. H. 1912 On the interstitial granules and fat droplets of striated muscle. Am. Journ. Anat., vol. 14, pp. 1-46.

1916 Fat and mitochondria in cardiac musele. Am. Jour. Anat., vol. 19, pp. 1-32. 
CowDRY, E. V. 1916 The general functional significance of mitochondria. Am. Jour. Anat., vol. 19, pp. 423-446.

Fischer, M. H., ANd Hooker, M. O 1917 Eats and fatty degeneration, pp. $57-85$.

HATAT, S. 1915 The growth of the body and organs in albino rats fed with a lipoid-free ration. Anat. Rec., vol. 9, pp. 1-20.

Huber, G. C. 1909 The morphology and strueture of the mammalian renal tubule. Harvey lectures, 1909-1910, pp. 100-149.

IMrie, C. G. 1914 On fatty changes in the liver, heart and kidney, Journal of Pathology and Bacteriology, vol. 19, pp. 245-257.

KIngsBdry, B. F. 1911 The histological demonstration of lipoids. Anat. Rec., vol. 5, pp. 313-318.

1912 Cytoplasmic fixation, Anat. Rec., vol. 6, pp. 39-52.

1915 Histological technique, p. 7.

Kraus und Rosenfeld 1904 Fett degeneration u. Fett infiltration. Verh. d. D. path. Ges., VI, Jena.

Leathes, J. B. 1910 The fats, p. 1, pp. 117-124.

MacNider, W. D. 1916 Pathological study of naturally acquired nephropathy of the dog. Jour, of Med. Research, vol. 29.

1918 The stability of the acid-base equilibrium of the blood in naturally nephropathic animals, and the effect on renal function of changes in the equilibrium.

Mayer, A., Er Ratherf, Fr. 1909 Recherehes sur l'histo-physiologie de la sécretion urinaire chez les Mammifères. Archives d'Anatomie Microseopique, T. 11, pp. 134-166.

Motrram, V. H. 1916 Fat infiltration of the cat's kidney. Jour. of Biol. Chem., vol. 24. Proceedings of the American Society of Biological Chemists, p. XI-XII.

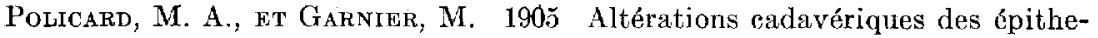
liums rénaux. Comptes Rendus Soc. Biol., T. 572, pp. 678-680.

Policard, M. A. 1905 Sur les formations, mitochondriales du rein des vertébrés. Comptes Rendus Soc. Biol., T. 572, pp. 380-382.

1910 Contribution à l'étude di mécanisme de la sécretion urinaire. Le fonctionnement du rein de la Grenouille. Archives d'Anatomie microseopique, T. 12 , pp. 177-287.

1912 Recherchés histophysiologiques sur les premiers stades de la sćcretion urinaire. Archives d'Anat. micro., T. 14, pp. 1-40.

1912 La cytogenèse du tube urinaire chez l'Homme. Archives d'Anat. micro., T. 14 , pp. $429-468$.

Sсотт, W. J. M. 1916 Experimental mitochondrial changes in the pancreas in phosphorus poisoning. Am. Jour. Anat., vol. 20, pp. 237-251.

ZIEGLeR, C. 1908 General pathology. Translation by H. S. Warthin, P. 199-200, 11th edition. 


\section{PLATE 1}

\section{EXPLANATION OF FIGURES}

1 Kidney of kitten, $22 \mathrm{~cm}$. in length, with little abdominal or subcutaneous fat. Radial section of tissue fixed in Benda's fluid shows lipoids blackened by osmic acid in medullary segments of proximal convoluted tubule. Photograph, $\times 24$.

3 Kidney of kitten, $19 \mathrm{~cm}$. in length, very fat, not yet weaned. Radial section of tissue fixed in Benda's fluid shows lipoids blackened by osmic acin in labyrinth. Photograph, $\times 44$.

4 Kidney of kitten, same as figure 3. Tangential section shows labyrinth blackened, rays unstained. Photograph, $\times 44$.

5 Kidney of kitten, $23 \mathrm{~cm}$. in length, fair amount of abdominal and subcutaneous fat. Radial section of tissue fixed in 10 per cont dichromate and osmic acid without heat shows blackened medullary segments in rays in cortex and ascending limbs of medullary loop in outcr zone of medulla. Photograph, $\times 16$.

6 Kidney of kitten, same as figure 5. Radial section, same as figure 5. Photograph, $\times 44$.

7 Kidncy of kitten, same as figure 5. Tangential section shows medullary segments of proximal convoluted tubule in cross-section. Photograph, $\times 44$. 
CHRSTIASTA SMTTH

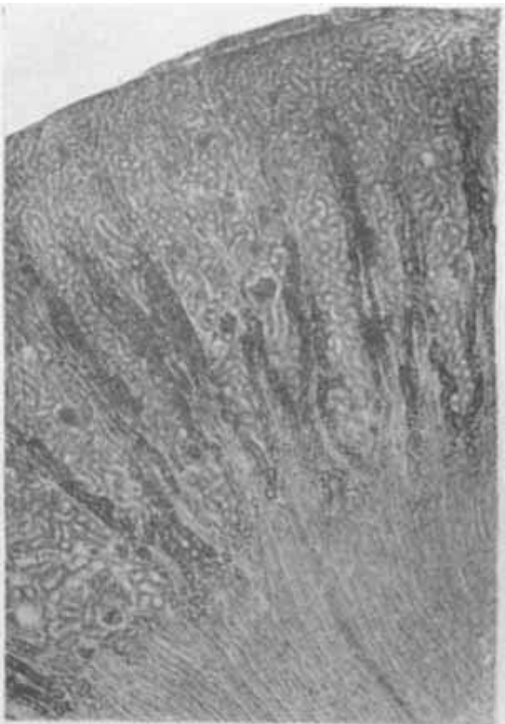

1

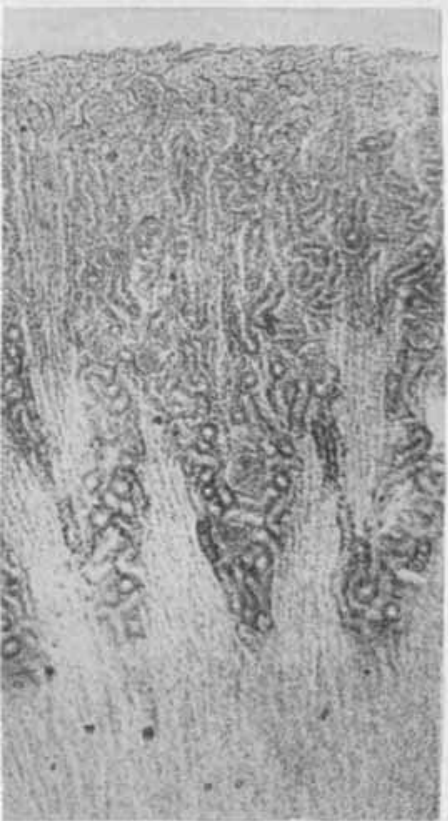

3

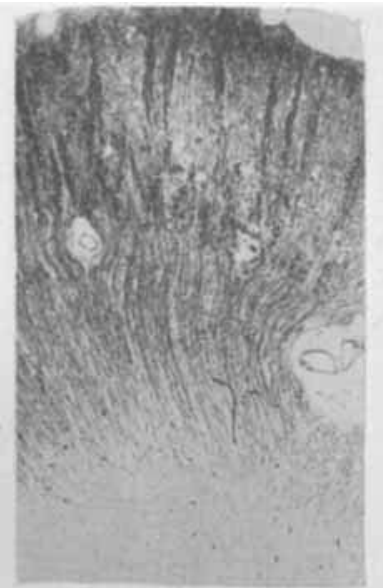

5

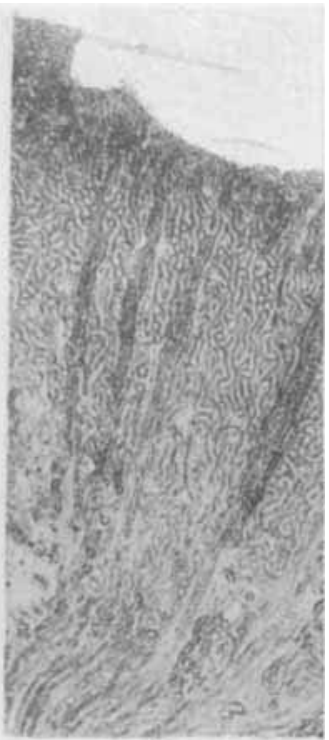

6

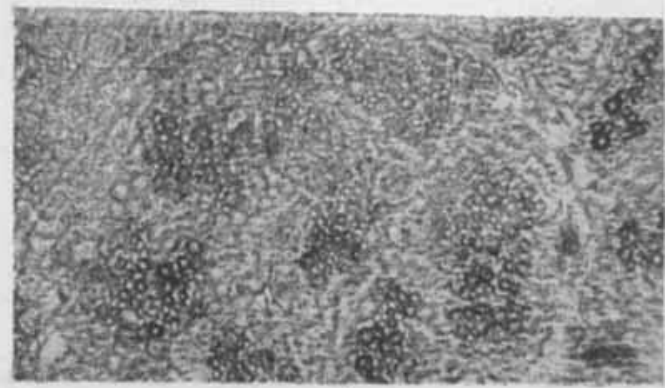

7

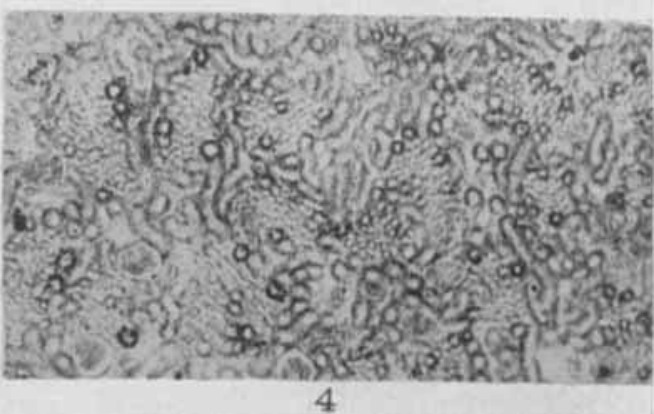

4

95

THE AMERTCAN JOLRNAL OF A.YATOMY, YOL. 27 , NO, 1 


\section{PLATE 2}

\section{EXPIANATION OF FIGURES}

2 Kidney of kitten, same as figure 1. Tangential section shows cross-section of medullary segments of proximal convoluted tubule rays. Photograph, $\times 44$.

8 Kidney of cat, $48.5 \mathrm{~cm}$. in length, very fat kidney. Radial section of tissue fixed in Flemming's fluid shows labyrinth intensely black, medullary rays unstained. Photograph, $\times 16$.

9 From kidney of kitten, same as figure 1. Transection of tubules from tissuc fixed in 10 per cent dichromate and staincd in sudan III shows granular and homogeneous rods of ascending limbs, stained mostly at periphery, few solid granules, granules in descending limb and collecting tubule. Projection drawing, $\times 800$.

$10 \mathrm{Kidney}$ of eat, $46 \mathrm{~cm}$. in length, little abdominal or subeutaneous fat, liver pathological. Kidney light in color. Transection of tissue fixed in 10 per cent dichromate, stained in sudan III. Shows racuoles in proximal convoluted tubulcs, rods, and granules stained in ascending limb of medullary loop. Projection drawing, $\times 800$.

11 Transection of trubule of ascending limb of medullary loop of kidney of puppy, $23 \mathrm{~cm}$. long. Tissue fixed in 10 per cent dichromate and osmic acid, and shows granular rods staining black. Projection drawing, $\times 800$.

12 Same as figure 10 . Transcetion of proximal convoluted tubule and medullary segment to show vacuoles and granules staining with sudan III. Projection drawing, $\times 800$.

13 Transection of medullary segment of proximal eonvoluted tubule and ascending limb of Henle's loop. Compare figure 1. Tissue fixed in 10 per cent dichromate and osmic acid with heat. There are here shown granular rods staining black in the ascending limb. Projection drawing, $\times 1200$.

14 Transection of tubule of kidney. The same as figure 5 . It shows lincar arrangement of lipoid granules in the proximal convoluted tubule. Projection drawing, $\times 1200$. 
CHRISTIANNA SMITH

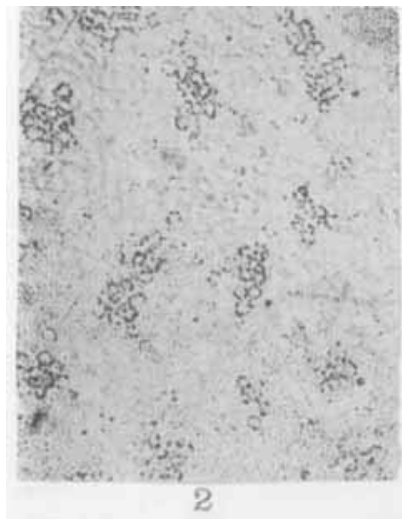

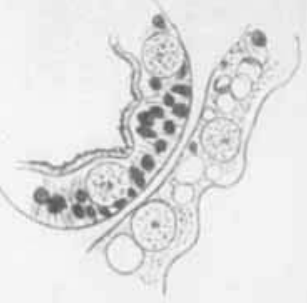

12
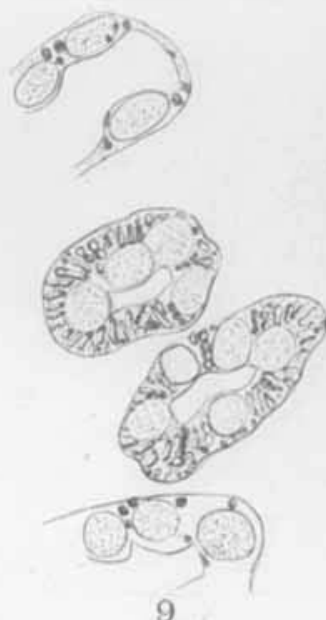

9

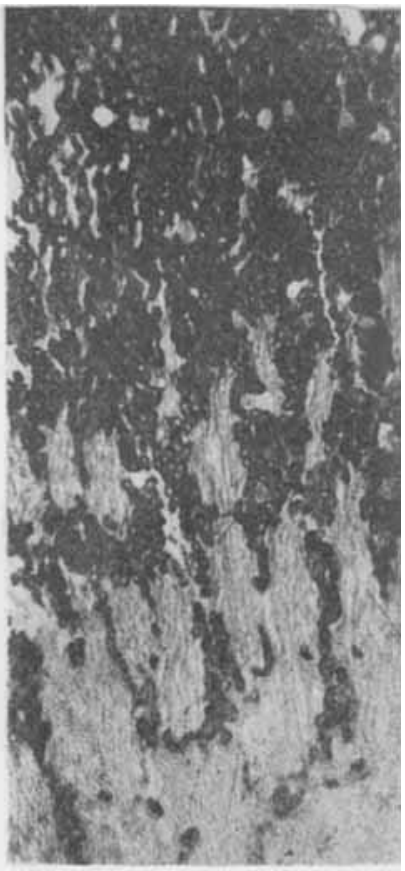

8

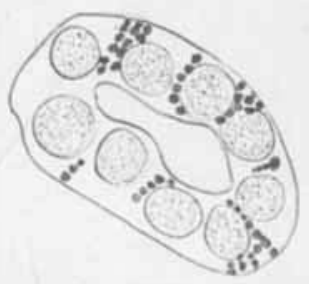

11

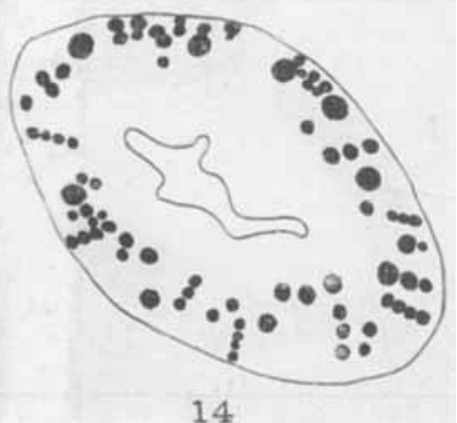

14 